\title{
Establishment of Cell Lines from Slender Walking Catfish Clarias nieuhofii (Valenciennes, 1840)
}

\section{Monthon LERTWORAPREECHA ${ }^{1, *}$, Chiraprapha TUYARUM ${ }^{1}$, Alongklod TANOMTONG ${ }^{2}$, Chatmongkon SUWANNAPOOM ${ }^{3}$ and Suphada KIRIRATNIKOM ${ }^{4}$}

\author{
${ }^{I}$ Microbiology Program, Department of Biology, Faculty of Science, Thaksin University, \\ Phatthalung 93210, Thailand \\ ${ }^{2}$ Toxic Substance in Livestock and Aquatic Animals Research Group, Department of Biology, \\ Faculty of Science, Khon Kaen University, Khon Kaen 40002, Thailand \\ ${ }^{3}$ Department of Fishery, School of Agriculture and Natural Resources, University of Phayao, \\ Phayao 56000, Thailand \\ ${ }^{4}$ Fisheries Science and Water Resources Program, Department of Biological and Environmental Science, \\ Faculty of Science, Thaksin University, Phatthalung 93210, Thailand
}

('Corresponding author's e-mail: worapreecha@gmail.com)

Received: 26 June 2020, Revised: 28 February 2021, Accepted: 5 March 2021

\begin{abstract}
The slender walking catfish (Clarias nieuhofii Valenciennes, 1840) is a freshwater fish found in the ecosystems within the peat swamp forests of South-East Asian countries, including Thailand. In this study, a new testis fibroblast-like (FLT) and ovary epithelial-like (ELO) cells derived from C. nieuhofii (Valenciennes, 1840) was established. The optimal number of both cells was determined, and the optimal starting concentration of both cells is approximately $10^{5}$ cells $\cdot \mathrm{ml}^{-1}$. The FLT and ELO can grow best at $28{ }^{\circ} \mathrm{C}$ in DMEM supplemented with 20,15 , and $10 \%$ fetal bovine serum (FBS). Chromosome analysis revealed that the typical diploid chromosome number was 66 (2n) in C. nieuhofii (Valenciennes, 1840). In both males and females, the elementary number of chromosomes (NF; the number of chromosome arms) was 98. No heteromorphic chromosome was observed. Four types of chromosomes were found in this species, including 14 metacentric, 20 submetacentric, 2 acrocentric, and 30 telocentric chromosomes. The FLT and ELO cells were maintained up to 6 months with more than 20 passages successfully cryopreserved and thawed.
\end{abstract}

Keywords: Clarias nieuhofii (Valenciennes, 1840), Ovary, Slender walking catfish, Testis

\section{Introduction}

Clarias nieuhofii (Valenciennes, 1840) (Family: Clariidae), known as the slender walking catfish, a freshwater fish, which is an essential species under the genus Clarias, is distributed in several South-East Asian countries, including Thailand [1,2]. Based on the Thailand Red Data: Fish, this species is rare and classified as a vulnerable species, which requires urgent conservation actions [3]. Since it is a fascinating catfish with beautiful body patterns, delicious meat, and high prices, it is often caught for food and ornamental purposes. Besides, the rapidly decreasing population of the slender walking catfish could also be attributed to the increasing encroachment of peat swamp forests, which is the natural habitat of this species. The slender walking catfish is essential in maintaining a balanced ecosystem within the peat swamp forests because it is among the few species which can grow in this environment. Knowledge and research in areas such as natural habitat, nutrition, artificial breeding, as well as infectious diseases and 
their prevention are essential towards the conservation of this species. Many researchers have used catfish as models for studying the pathogenesis of infectious agents and toxicology [4-6]. In the context described above, careful consideration of the ethical issues concerning the welfare of laboratory animals is required. The development of a fish cell line from the slender walking catfish has been considered an ideal step for an alternative pathway in researching to circumvent these problems. Fish cell lines are useful in many aspects, not only for viral isolations and research on pathogenesis of viral infections but also with contributions towards biomedical research. Several studies have developed in vitro tests for the study of toxicology, pathology, and immunity of fish, as in vitro tests make it easier to control the experiment's conditions. The combination of cell culture and in vitro assay reduced the variability in vivo responses due to stress, environmental influences, and diverse genetic backgrounds of fish species [7-9].

During the past 20 years, many fish cell lines have been established and characterized by a wide range of different fish species and tissues such as a kidney cell line from sea bass (Lates calcarifer Bloch, 1790) [10], a fibroblast cell line from the dorsal fin of red sea bream, (Pagrus major Temminck and Schlegel, 1843) [11] and a retinal pigmented epithelial cell line from zebrafish (Danio rerio Hamilton, 1822) [12]. Although cell lines from the walking catfish, such as the Indian walking catfish (Clarias batrachus Linaeus, 1758), have recently been established and characterized, cell lines from the fish species of concern are always recommended over the model cell lines when it comes to virus isolation and the study of pathogenesis at cellular and molecular levels [13]. Thus, the development of a fish cell line from the slender walking catfish is considered a better representation of this particular species than the other commonly used fish cell lines or mammalian cell lines.

This study aims to establish cell lines and optimal cell growth conditions as well as characterize the chromosomes from slender walking catfish. It reports on a new fibroblast-like cell from testis designed as FLT and epithelium-like cell from ovary designed as ELO, derivedfrom C. nieuhofii (Valenciennes, 1840).

\section{Materials and methods}

Primary culture of $C$. nieuhofii (Valenciennes, 1840) cell

A healthy six slender walking catfishes of males and females ages 6-8 months from the Aquaculture Research Unit of Thaksin University (Phatthalung Campus) were used in this study. All fishes were maintained in a laboratory aquarium containing freshwater supplemented with penicillin (Bio Basic Inc: Canada) 1,000 IU $\cdot \mathrm{ml}^{-1}$ and streptomycin (Bio Basic Inc: Canada) $1,000 \mu \mathrm{g} \cdot \mathrm{ml}^{-1}$. The water was being changed once a day for up to 3 days. The fish was anesthetized by $20 \mathrm{ppm}$ clove oil (final concentration in water) then the fish was subsequently euthanized by placing in ice for 30-40 min. Subsequently, to reduce contamination, after the process of euthanasia, the fish was immersed in $70 \%$ ethanol for 5 min. The fish was aseptically dissected inside a biosafety cabinet (MICROTECH: Thailand). The testis and ovary tissues were cut out and washed twice in Hank's balanced salt solution (HBSS) consist of a mixture of penicillin and streptomycin $\left(1,000 \mathrm{IU} \cdot \mathrm{ml}^{-1} ; 1,000 \mu \mathrm{g} \cdot \mathrm{ml}^{-1}\right)$ and finally washed with Dulbecco's Modified Eagle Medium (DMEM), (Gibco: USA) containing a mixture of penicillin and streptomycin $\left(1,000 \mathrm{IU} \cdot \mathrm{ml}^{-1} ; 1,000 \mu \mathrm{g} \cdot \mathrm{ml}^{-1}\right)$. The primary cell culture was generated using a tissue explant technique [14]. In brief, the tissues were minced into small pieces (approx. $1 \mathrm{~mm}^{3}$ ) and placed into a 6-well tissue culture plate that was coated with $50 \mu \mathrm{l}$ of fetal bovine serum (FBS) (Hyclone: USA). The dish was placed in a $\mathrm{CO}_{2}$ incubator and supplied with $5 \% \mathrm{CO}_{2}$, at $28{ }^{\circ} \mathrm{C}$ for $3 \mathrm{~h}$. After tissue attachment, $3 \mathrm{ml}$ of DMEM, supplemented with $10 \% \mathrm{FBS}$, was gently added into each well. The culture medium was refreshed every three days until confluence throughout the well.

\section{Optimization of the effects of cell density and culture medium on cell growth}

The confluent monolayer of FLT and ELO cells at the $20^{\text {th }}$ passage was subcultured by trypsinization with $0.25 \%$ trypsin (Himedia: India) and seeded into triplicates wells of 6-well plate at cell densities of $10^{3}, 10^{4}$, and $10^{5}$ cells $^{\prime} \mathrm{ml}^{-1}$ in Leibovitz's 15 (L-15) medium (Gibco: USA), M199 Gibco: USA), as well as in DMEM, supplemented with $10 \%$ FBS. Cell growth was determined by measurement of cell density every $24 \mathrm{~h}$ after trypsinization. 


\section{Optimization of the effects of FBS concentration on cell growth}

The most suitable medium, according to the above experiment, was further selected to optimize the effects of serum concentration on the growth of FLT and ELO cells. The experiment was done in triplicates in the selected medium supplemented with $5,10,15$, and $20 \%$ of FBS. The growth rate of the cells was determined by measuring the viability cells via trypan blue staining and counted microscopically every $24 \mathrm{~h}$.

\section{Chromosome preparation and karyotype study}

A Karyotype study was performed before the establishment of the cells and after culture for approximately 20 passages. To initiate a karyotype study, we used cells of the testis and ovary tissue as a representative for the $C$. nieuhofii (Valenciennes, 1840) chromosome. The final karyotype study was performed in both FLT and ELO cells. The chromosome was prepared according to the methods of [15]. Phytohemagglutinin (PHA) (Himedia: India) solution was injected into the abdominal cavity of the fish. After $24 \mathrm{~h}$, the colchicine (Himedia: India) was injected into the intramuscular of the fish individually and was left for $2-4 \mathrm{~h}$. Testis was selected and minced into small pieces before squash mixed with $0.075 \mathrm{M}$ potassium chloride (KCL) (Himedia: India). After filtering out the large tissues by cell strainer, the cell pellet was collected by centrifugation at 1,200 rpm for $8 \mathrm{~min}$, and then the $\mathrm{KCl}$ was discarded. The cell pellet was fixed by gradually adding $8 \mathrm{ml}$ of a fresh, cooling fixative agent (3 methanol: 1 glacial acetic acid), and then the fixed cell pellet was repeatedly centrifuged at $700 \mathrm{~g}$ for $10 \mathrm{~min}$. The fixation processes were repeated 3-4 times until the supernatant was clear, and finally, the pellet was added with $1 \mathrm{ml}$ fixative. The fixed pellet mixture was mounted onto a cold slide and let dry completely before staining. The mounted slide was stained using $20 \%$ Giemsa's solution for $30 \mathrm{~min}$. After that, the slide was soaked in distilled water and air-dried completely before microscopic observation.

\section{Cryopreservation of cells}

The confluent monolayer of both cells at the 20th passage was trypsinized with $0.25 \%$ trypsin when reached $90 \%$ confluences. Cells in culture flask were rinsed with a cold $1 \times \mathrm{PBS}, \mathrm{pH} 7.4$, and transfer the cell suspension in a $50 \mathrm{ml}$ centrifuge tube. Cells were centrifuged and washed twice at $200 \times \mathrm{g}$ for $5 \mathrm{~min}$ with cold PBS. After centrifugation, pellets were resuspended in $1 \mathrm{ml}$ of cryopreservative medium (70\% DMEM basal medium, $20 \% \mathrm{FBS}$, and $10 \% \mathrm{DMSO})$. The pellets were counted, and cell density was adjusted to be $5 \times 10^{6}$ cell ml $^{-1}$. Next, the pellet cells were transferred into a sterile cryovial in $1 \mathrm{ml}$ and stored at $-80^{\circ} \mathrm{C}$. The viability of the stored cell was tested after stored at $-80^{\circ} \mathrm{C}$ for one week and three months. For the thawing cell, the cryovial was removed from $-80^{\circ} \mathrm{C}$ and quickly thawed by swirling the cryovial in the $37{ }^{\circ} \mathrm{C}$ water bath. Cells were centrifuged and washed twice at $200 \times \mathrm{g}$ for 5 min with cold PBS. The percentage of cell viability was determined by counting with a hemocytometer.

\section{Statistical analysis}

All statistical analysis was performed using GraphPad Prism Version 5 (GraphPad Software, Inc., CA, US). The analysis was analyzed by one-way analysis of variance (ANOVA) followed by Dunnetts's multiple comparison analysis. Statistical difference was considered significant when $p \leq 0.05$.

\section{Result and discussion}

Primary cultures fibroblast-like cell derived from testis (FLT) and epithelium-like cell derived from the ovary (ELO)

Primary cell culture grew from testis and ovary tissues after explantation. The conditions for cell culture were decided based on the habitat of slender walking catfish that generally lives at a water temperature of approximately $26-28{ }^{\circ} \mathrm{C}$. Therefore, for all experiments, the cells were cultured and maintained at $28^{\circ} \mathrm{C}$ in an incubator supplied with $5 \% \mathrm{CO}_{2}$. Approximately $3-5$ days post explantation, both FLT and ELO cells begin to grow and expand from the edge surrounding the tissues (Figures 1a and 1c). The confluent monolayer cells achieved 60\% between 8-10 days. After 20 passages, most of the FLT cell was gradually predominated with bipolar or multipolar stretched slender and fusiform shape. 
http://wjst.wu.ac.th

The morphology suggested that the FLT probably be a fibroblast cell (Figure 1b). Unlike the FLT cell, the ELO cell typically showed polygonal in a form with higher regular dimensions, which suggested that the ELO is probably an epithelial cell (Figure 1d). After freezing at $-80{ }^{\circ} \mathrm{C}$ for one week, determining the viability of cells indicated that both cells were still alive and had a high recovery rate, which showed approximately $98 \%$ viability. However, the survival rate after 3 months for both FLT and ELO cells decreased from 98 to $60 \%$.
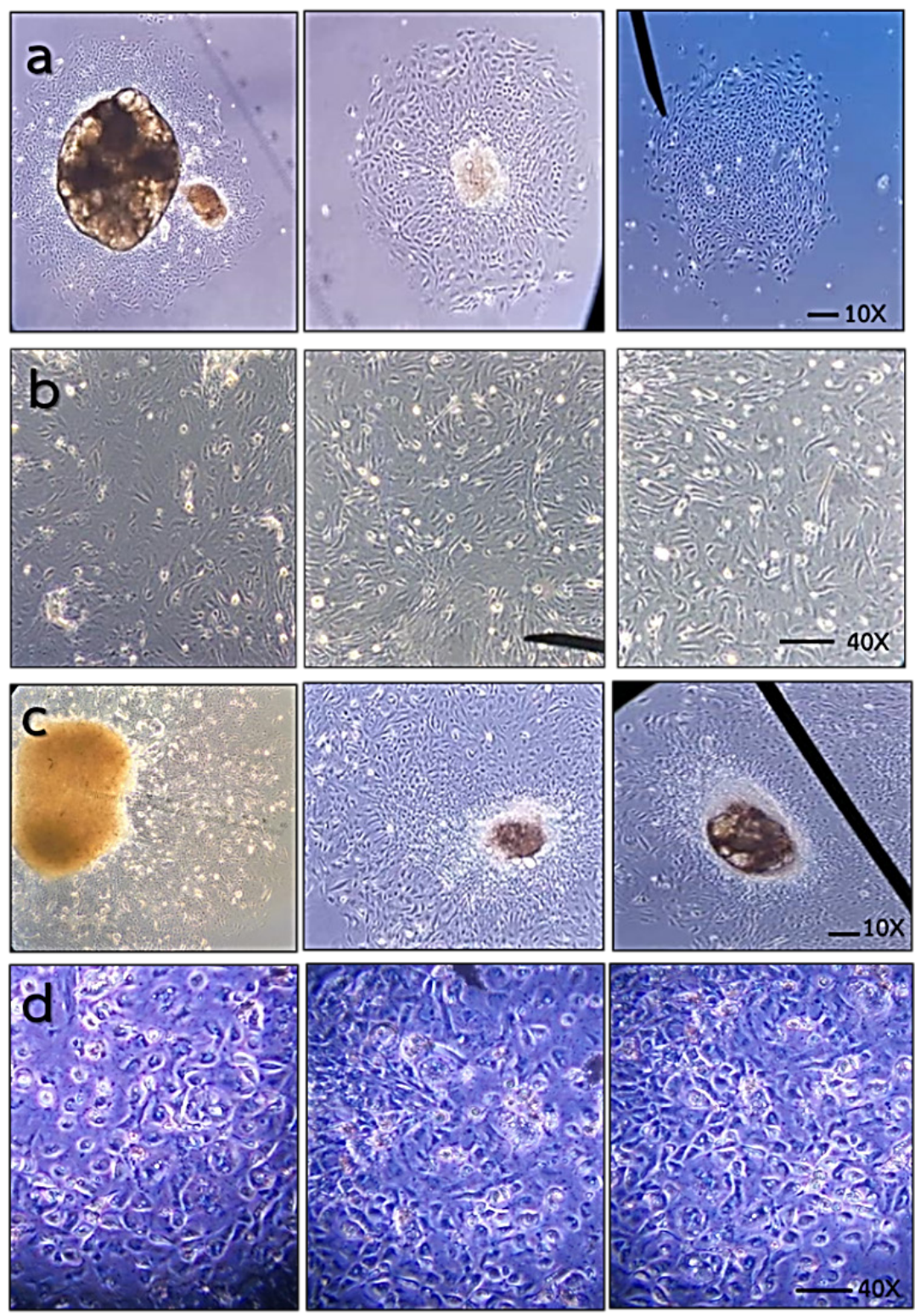

Figure 1 Monolayer cells of (a) the $C$. nieuhofii testis fibroblast-like (FLT), and (c) ovary epithelial-like cell (ELO). Growing of the 3 days (b) primary FLT and (d) ELO cells visible surround the explanted tissues. The monolayer of fibroblast-like FLT and ELO cells at passages 25 (scale bar: $100 \mu \mathrm{m}$ ). 
http://wjst.wu.ac.th

\section{Effects of cell density on cell growth}

Since the growth of some specific cells needs signals from communication, contact of each neighbor cells that allowed the cells to grow well, therefore, the different number of cell density at $10^{3}, 10^{4}$, and $10^{5}$ cells $\cdot \mathrm{ml}^{-1}$ in DMEM supplemented with $10 \% \mathrm{FBS}$ was used to determine the growth rate of both cells. The results demonstrated that the cell initial density has a noticeable significant effect on the growth of both FLT and ELO cells. Both FLT and ELO in DMEM grew better during initial cultivation with $10^{5}$ cells $\cdot \mathrm{ml}^{-1}$. The initial cell culture with a lower cell number of $10^{3}$ and $10^{4}$ cells $\cdot \mathrm{ml}^{-1}$ exhibited a relatively slower growth rate (Figures $\mathbf{2 a}$ and $\mathbf{2 b}$ ). According to the result, we, therefore, selected the original cell number at $10^{5}$ cells $\cdot \mathrm{ml}^{-1}$ for further optimization with different mediums and concentrations of FBS.
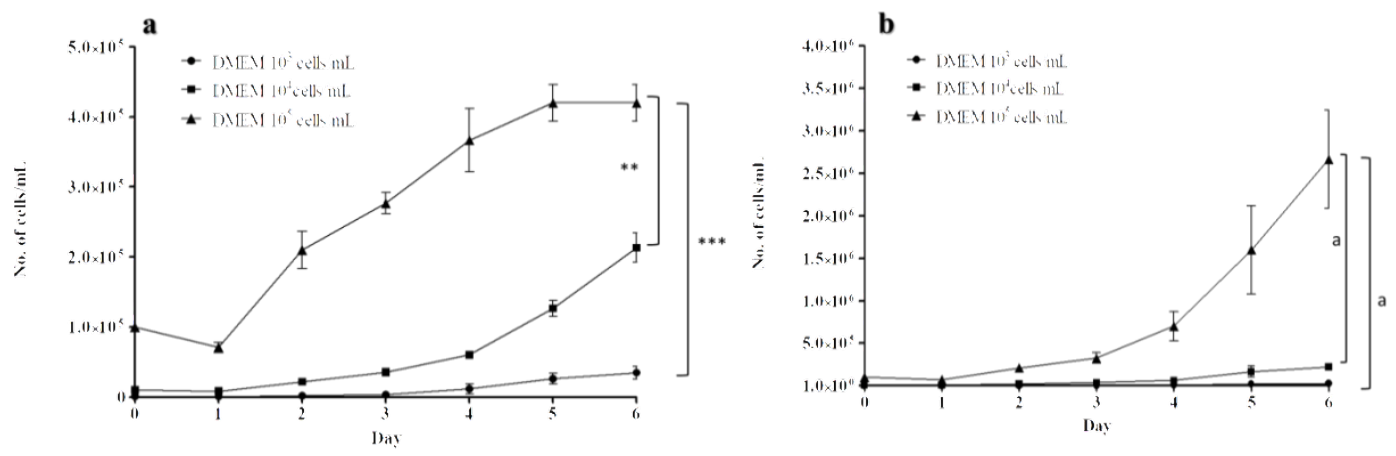

Figure 2 Growth curve of FLT and ELO cell to initial of initial different cell density culture with DMEM, (a) C. nieuhofii testis fibroblast-like (FLT), (b) ovary epithelial-like cell (t-test comparison the mean at the day $\left.6 ; * * p=0.0076, * * * p=0.0006,{ }^{a} p=<0.001\right)$.
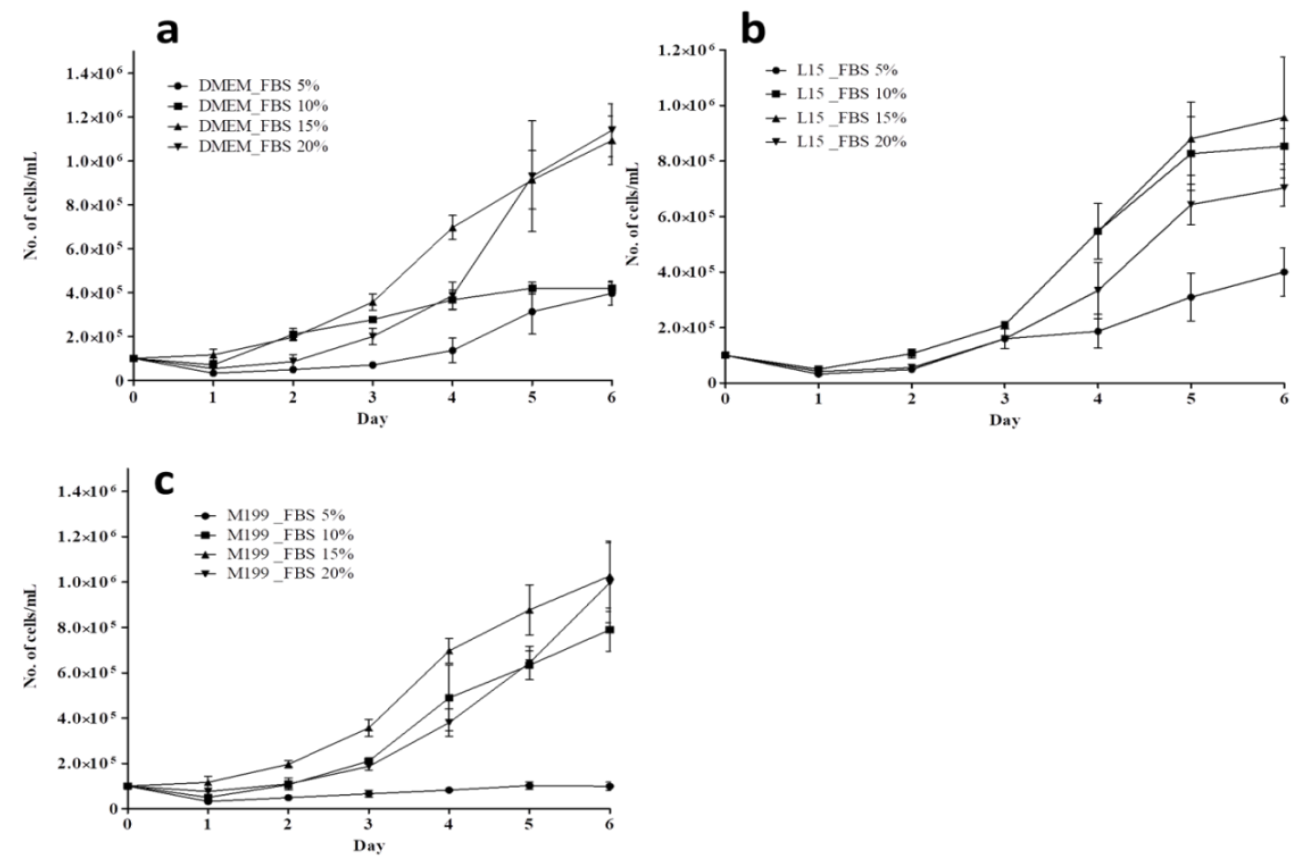

Figure 3 The effects of the culture medium and suitable concentration of FBS on growing of FLT, (a) FLT cell culture in DMEM supplemented with different FBS at 5, 10, 15 and $20 \%$; (b) FLT cell culture in L-15 supplemented with different FBS at 5, 10, 15, and $20 \%$; (c) FLT cell culture in M199 DMEM supplemented with different FBS at 5, 10, 15 and $20 \%$. 
http://wjst.wu.ac.th

\section{Effects of the culture medium and concentration of FBS on cell growth}

To test the consequences of the culture medium and appropriate concentration of FBS on growing of both FLT and ELO cells at $10^{5}$ cells $\cdot \mathrm{ml}^{-1}$ were cultured with M199, DMEM, and L-15 supplemented with different FBS concentrations $(5,10,15$, and $20 \%$ ). The cells were counted in every $24 \mathrm{~h}$ for six days. After the $6^{\text {th }}$ day, the FLT cells in DMEM supplemented with $20 \%$ FBS, showed the highest in cell number followed by $15 \%$ FBS, but there is no statistically significant difference between different serum concentrations observed in DMEM as in L-15 and M199 medium.

Overall, the number of FLT cells can increase from $10^{5}$ to $10^{6} \mathrm{cells} \cdot \mathrm{ml}^{-1}$ within six days. The exponential growth of the FLT cell was observed between days 3 through days 5. Whereas the FLT cell culture at a low concentration of FBS showed insufficiently promote the growth of the FLT cell until day 6 (Figure 3a). Although the growing of FLT cells in all three types of the medium is slightly different, it seems that in the DMEM medium, it is the best medium to promote cell growth. The result of the ELO cell was slightly different from the FLT cell, which indicated that DMEM supplemented with $10 \%$ FBS was the most suitable medium to promote cell growth (Figure 4a). Although the supplementation with 15 - $20 \%$ FBS in the DMEM medium exhibited a slightly lower growth rate than $10 \%$ FBS, the statistical analysis indicated no statistically significant difference. According to the FLT cell result, growing of ELO cells in M199 and L-15 medium supplemented with different FBS concentrations is lower than DMEM (Figure 4b and 4C). In summary, the result indicated that the DMEM medium was suitable for the growth of both FLT and ELO cells, and statistical analysis revealed that supplementation of FBS with 10 - $20 \%$ did not show a significant difference. Therefore, for further study, DMEM medium supplemented with 15 and $10 \%$ was chosen for the FLT cell and ELO cell.
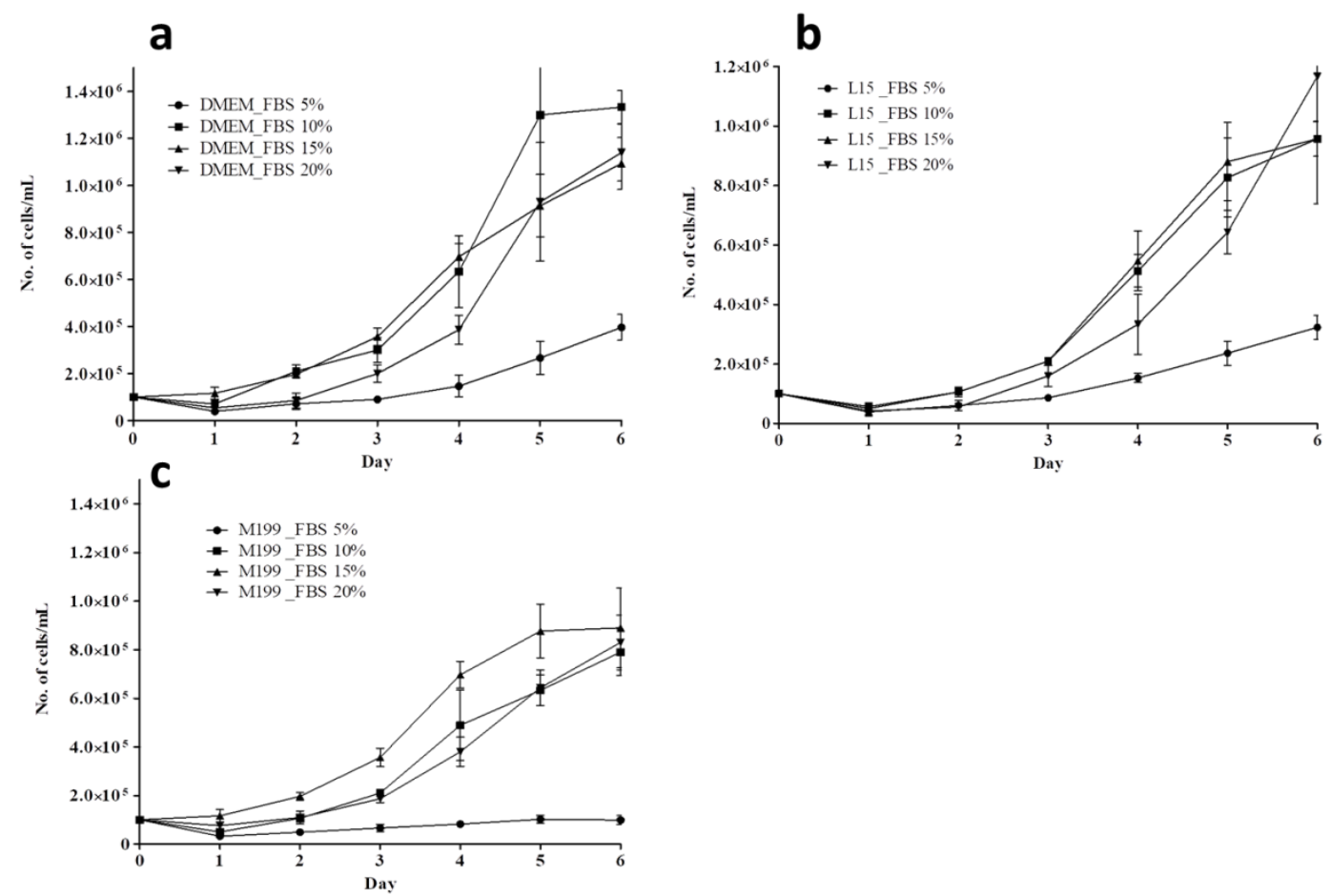

Figure 4 The effects of the culture medium and suitable concentration of FBS on growing of ELO, (a) ELO cell culture in DMEM supplemented with different FBS at 5, 10,15 and 20\%; (b) ELO cell culture in L-15 supplemented with different FBS at 5, 10,15 and 20\%; (c) ELO cell culture in M199 DMEM supplemented with different FBS at 5, 10, 15 and $20 \%$. 
Establishment of cell lines, several factors that affect the growth of cells such as initial cell density, type of culture medium, and serum concentration must be considered. Culture of both FLT and ELO with low initial cell density at $10^{3}, 10^{4}$ cells $\cdot \mathrm{ml}^{-1}$ showed slow growth rates. Increasing the rate of both cell growth can be achieved when starting the cell density at $10^{5}$ cells $\cdot \mathrm{ml}^{-1}$; this suggests that contact communication is necessary. Usually, the number of excess cells will inhibit the growth of cells resulting from contact inhibition. However, the low density of cells in culture delayed the growing of cells because signal communications via cell to cell contact and from mediators are low [16]. It has demonstrated that cell survival and growth can improve via cell feeder layers or conditioned media [17,18]. Optimization of serum concentrations and type of culture medium revealed that both cells could grow better in DMEM than in L-15 medium, but FLT cell grows slowly than ELO cell and requires more serum concentration. Generally, using fish serum (FS) or fish meat extract (FME) from the same species may help to promote the growth of fish cells better; however, preparation of FME and FS requires many fish, time-consuming, and cumbersome [19]. FBS is a crucial constituent supplemented in an animal cell culture medium since it is not the only source of growth-promoting factors, but FBS also provides adhesion factors such as fibronectin and vitronectin [20]. Besides, our result indicated that the concentration of FBS has a critical factor for growing both cells because the exponential growth rate exhibited increased serum concentration in the culture medium. However, increased FBS concentration to $20 \%$ resulted in the inhibition of FLT growth. This study is consistent with previous reports indicated that the amount of FBS that exceeds $20 \%$ slows down or inhibits cell growth [21]. The inhibitory factors have been reported in FBS, and the inhibitory effects on cell proliferation and differentiation have also been shown in mouse keratinocytes and murine corneal epithelial cells [22].

\section{Karyotype study}

For the first time, this study examined the chromosomal characteristics and karyological analysis of the $C$. nieuhofii (Valenciennes, 1840) from Thailand. The diploid chromosome number was 66 (2n) in $C$. nieuhofii (Valenciennes, 1840). The fundamental numbers (NF; the number of chromosome arms) were 98 in both males and females. No heteromorphic chromosome was observed, which could be considered as sex-chromosome. Four types of chromosomes were found in this species, including 14 metacentric, 20 submetacentric, 2 acrocentric, and 30 telocentric chromosomes (Figures 5a and 5b). After approximately 20 passages, the karyotyping study was repeated for both FLT and ELO cells. The results showed no changes found in the karyotypic characteristic in both cell types that the chromosome isolated from $C$. nieuhofii (Valenciennes, 1840). The metaphase chromosome representative from the ELO cell was shown in Figures 5c and $\mathbf{5 d}$.

Chromosomal differences between Clarias species are also consistent with the morphological differences of the catfish. The noteworthy difference between the $2 \mathrm{n}$ and NF values in different Clarias species suggests that different chromosome arrangements have probably appeared during the evolution [23]. Several species within the genus Clarias examined to date, $2 \mathrm{n}$ interval between $2 \mathrm{n}=48$ and $2 \mathrm{n}=66$, except for one population of $C$. batrachus (Linnaeus, 1758) $2 \mathrm{n}=100$ ) [24]. Besides, some sexchromosomes and B chromosomes have also been found in some of these Clarias species [25]. This present study is the first cytogenetic study on C. nieuhofii (Valenciennes, 1840) accomplished with the conventional staining technique. 

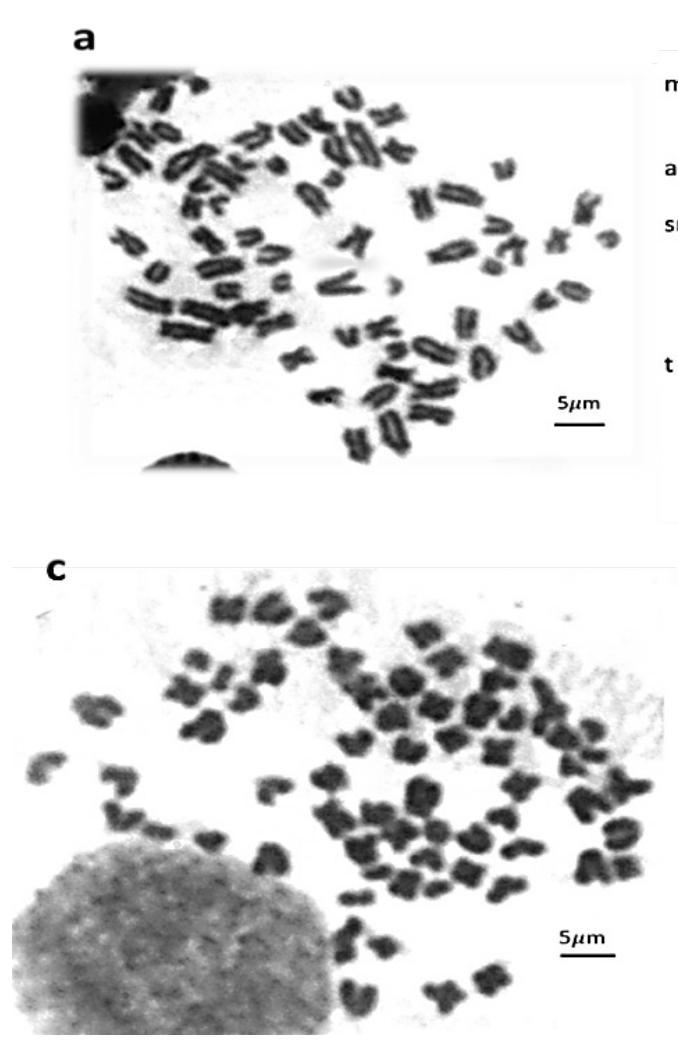

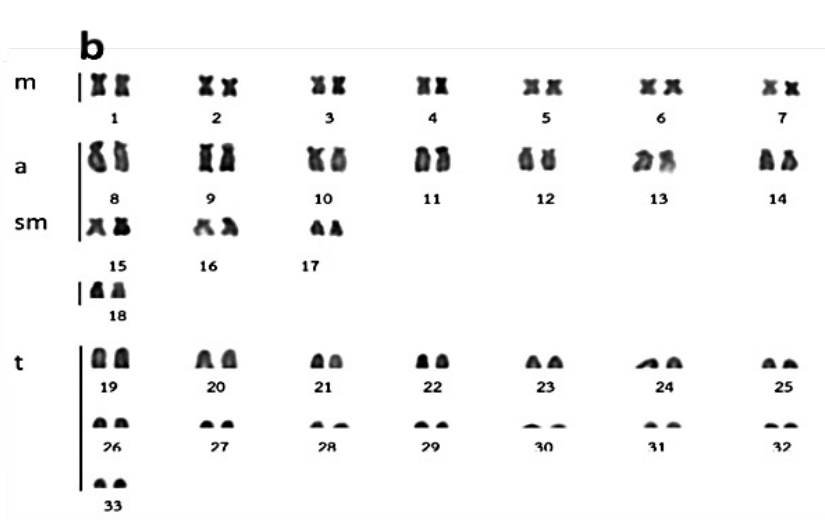

d

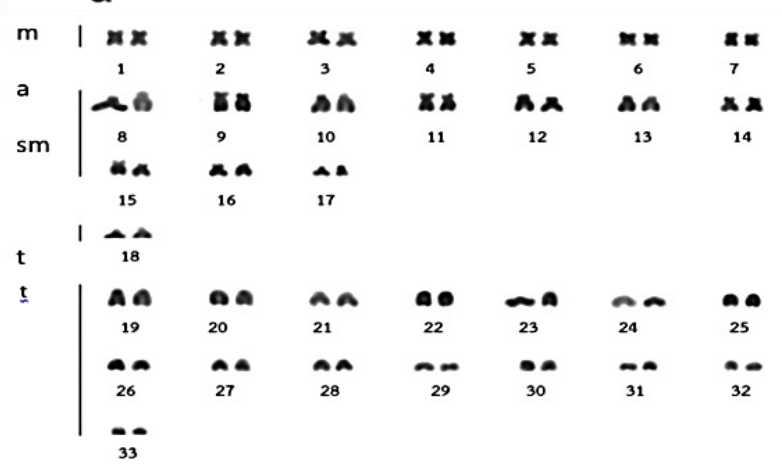

Figure 5 Metaphase chromosome plate from female Clarias nieuhofii (a) and karyotype (b) of Clarias nieuhofii $(\mathrm{n}=6)$ by conventional staining technique. Scale bar $=5 \mu \mathrm{m} . \mathrm{m}=$ Metacentric, $\mathrm{sm}=$ Submetacentric, $\mathrm{a}=$ Acrocentric, $\mathrm{t}=$ Telocentric ( $\mathrm{c}$ and $\mathrm{d}$ ) Metaphase chromosome representative of the ELO cell at the passages 50 .

\section{Conclusions}

This study attempted to develop a cell line from slender walking catfish, C. nieuhofii (Valenciennes, 1840), to use as a biological study model of fish in various fields as a substitute for slender walking catfish. A cell line developed in this study will hopefully be an essential tool for studying cell physiology, Environmental toxicology, Pathology of infectious diseases, bacteria, viruses, and different types of parasites. In this study's results, a new testis fibroblast-like (FLT) and ovary epithelial-like (ELO) cells derived from $C$. nieuhofii (Valenciennes, 1840) were established. Both cells can grow better in DMEM supplemented with 20 and $10 \%$ fetal bovine serum (FBS) at $28{ }^{\circ} \mathrm{C}$ and can maintain for over 50 passages. Chromosome analysis revealed that the typical diploid chromosome number was $662 \mathrm{n}$ ) in both males and females. No heteromorphic chromosome was observed. Four types of chromosomes were found in this species, including 14 metacentric, 20 submetacentric, 2 acrocentric, and 30 telocentric chromosomes. Our results provide new cytogenetic information for further study on taxonomy and evolutionary relationships. The FLT and ELO cells have been maintained up to 6 months with more than 20 passages and successfully cryopreserved and thawed.

This report is the first to generate a cell line from the C. nieuhofii (Valenciennes, 1840) and the first report on the chromosomal characteristics of the fish. We expect that both types of cells will be useful for future slender walking catfish studies. 


\section{Acknowledgement}

This study was supported by a government endowment fund 2017(Code_RO1-2560A10502024), Research and Development Institute, Thaksin University, Thailand, and Toxic Substance in Livestock and Aquatic Animals Research Group, Khon Kaen University, Thailand. Special thanks to the Unit of Excellence 2021 on Genetic diversity assessment of widely distributed aquatic animals and herpetology from Thailand (UoE64003) for facilities and karyotyping study. This study has endorsed by the Ethics Committee of the Laboratory of Animal Research; Thaksin University, Thailand (permitted number $64.26 / 22722)$.

\section{References}

[1] BS Santos, FPC Vesagas, MTC Tan, JC Jumawan and JP Quilang. Status assessment of clarias species in the Philippines: Insights from DNA barcodes. Sci. Diliman. 2015; 27, 21-40.

[2] M Kottelat, AJ Whitten, SN Kartikasari and S Wirjoatmodjo. Freshwater fishes of Western Indonesia and Sulawesi. Periplus Editions, Hong Kong, 1993, p. 221.

[3] C Vidthayanon. Thailand Red Data: Fishes. Office of Natural Resources and Environmental Policy and Planning, 2005.

[4] M Ibrahem. Experimental exposure of African catfish Clarias Gariepinus (Burchell, 1822) to phenol: Clinical evaluation, tissue alterations and residue assessment. J. Adv. Res. 2012; 3, 177-83.

[5] G Ichihara, J Kitoh, W Li, X Ding, S Ichihara and Y Takeuchi. Neurotoxicity of 1-bromopropane: Evidence from animal experiments and human studies. J. Adv. Res. 2012; 3, 91-8.

[6] D Zhang, G Moreira, C Shoemaker, N Joseph and DH Xu, Detection and quantification of virulent Aeromonas hydrophila in channel catfish tissues following waterborne challenge. FEMS Microbiol. Lett. 2016; 363, 1-5.

[7] E Ariel, HF Skall and NJ Olesen. Susceptibility testing of fish cell lines for virus isolation. Aquaculture 2009; 298, 125-30.

[8] U Kammann, M Bunke, H Steinhart and N Theobald. A permanent fish cell line (EPC) for genotoxicity testing of marine sediments with the comet assay. Mutat. Res-Gen. Tox. En. 2001; 498, 67-77.

[9] G Taju, SA Majeed, KSN Nambi and ASS Hameed. Application of fish cell lines for evaluating the chromium induced cytotoxicity, genotoxicity and oxidative stress. Chemosphere 2017; 184, 1-12.

[10] ASS Hameed, V Parameswaran, R Shukla, ISB Singh, AR Thirunavukkarasu and RR Bhonde. Establishment and characterization of India's first marine fish cell line (SISK) from the kidney of sea bass (Lates calcarifer). Aquaculture 2006; 257, 92-103.

[11] $\mathrm{CC} \mathrm{Ku}, \mathrm{CH} \mathrm{Lu}$, and $\mathrm{CS}$ Wang, Establishment and characterization of a fibroblast cell line derived from the dorsal fin of red sea bream, Pagrus major (Temminck \& Schlegel). J. Fish Dis. 2010; 33, 187-95.

[12] KSN Nambi, SA Majeed, G Taju, S Sivasubbu, NS Raj, N Madan and ASS Hameed. Development and use of retinal pigmented epithelial cell line from Zebrafish (Danio rerio) for evaluating the toxicity of ultraviolet-B. Zebrafish 2015; 12, 21-32.

[13] VS Babu, KSN Nambi, V Chandra, VPI Ahmed, R Bhonde and ASS Hameed. Establishment and characterization of a fin cell line from Indian walking catfish, Clarias batrachus (L.). J. Fish. Dis. $2011 ; 34,355-64$.

[14] G Rathore, G Kumar, TR Swaminathan, N Sood, V Singh, R Abidi and W Lakra. Primary cell culture from fin explants of Labeo rohita (Ham.). Indian J. Fisher. 2007; 54, 93-7.

[15] W Supiwong, A Tanomtong, A Chaveerach, T Tanee, S Khakhong and LO Sanoamuang. Interpopulational variation of NOR positions and Karyotypic analysis of siamese catfish (Pseudomystus siamensis) in Thailand. Cytologia 2013; 78, 25-34.

[16] RI Freshney. Culture of Animal Cells: A Manual of Basic Technique. John Wiley \& Sons, 2000. 
[17] Z Fan, L Liu, X Huang, Y Zhao, L Zhou, D Wang and J Wei. Establishment and growth responses of Nile tilapia embryonic stem-like cell lines under feeder-free condition. Dev. Growth Differ. 2017; 59, 83-93.

[18] JG Xing, W El-Sweisi, LE Lee, P Collodi, C Seymour, C Mothersill and NC Bols. Development of a zebrafish spleen cell line, ZSSJ, and its growth arrest by gamma irradiation and capacity to act as feeder cells. In Vitro Cell. Dev. Biol. Animal 2009; 45, 163-74.

[19] G Rathore, N Sood and TR Swaminathan. Primary cell culture from fish gills and kidney using fish serum. Indian J. Exp Biol. 2001; 39, 936-38.

[20] EG Hayman, MD Pierschbacher, S Suzuki and E Ruoslahti. Vitronectin-A major cell attachmentpromoting protein in fetal bovine serum. Exp. Cell Res. 1985; 160, 245-58.

[21] J Qin, J Xu and P Xie. Diet overlap between the endemic fish Anabarilius grahami (Cyprinidae) and the exotic noodlefish Neosalanx taihuensis (Salangidae) in Lake Fuxian, China. J. Freshwater Ecol. 2007; 22, 365-70.

[22] F Bertolero, ME Kaighn, RF Camalier and U Saffiotti. Effects of serum and serum-derived factors on growth and differentiation of mouse keratinocytes. In Vitro Cell. Dev. Biol. Animal 1986; 22, 423-28.

[23] N Maneechot, CF Yano, LAC Bertollo, N Getlekha, WF Molina, S Ditcharoen, B Tengjaroenkul, W Supiwong, A Tanomtong and MDB Cioffi. Genomic organization of repetitive DNAs highlights chromosomal evolution in the genus Clarias (Clariidae, Siluriformes). Mol. Cytogenet. 2016; 9, 4.

[24] J Eyo and J Effiong. Cytogenetic variations in Clarias species (Clariidae: Surulifromis) of the Anambra River using Leucocytes Culture Techniques. Anim. Res. Int. 200; 2, 275-86.

[25] R Arai and H Hirano. First record of the Clariid Catfish, (Clarias fuscus), from Japan. Japanese J. Ichthyol. 1974; 21, 53-60. 